\title{
THE TIMES AND
}

\section{APPEASEMENT}

The Journals of A. L. Kennedy,

1932-1939

\section{Edited by}

Gordon Martel

CAMDEN FIFTH SERIES

VOLUME 16 
he Kennedy journals

provide new and

interesting insight into the 8

relationship between The

Times, the government and the Foreign Office during the "age of appeasement? This selection from the journals focuses on the period 1932-1939, and recounts his discussions with Ramsay MacDonald, Arthur Henderson, John Simon, Anthony Eden and other leading British politicians, his meetings with Brüning, Ribbentrop, Dollfuss and other leading European politicians and diplomats. The inner workings of

The Times is revealed through his relationships with Geoffrey Dawson and Robin BarringtonWard, while the relationship between the newspaper and the Foreign Office is recounted in his renderings of Robert Vansittart, Reginald Leeper. Arthur Willert and others. The journals are a remarkable record of his attempts

to make sense of Hitler and Nazism, Mussolini and Fascism. and to determine how Britain ought to respond to the challenges they posed. Students of journalism and politics will discover in vivid detail how a journalist attempts simultaneously to understand and to shape 'public opinion' and fresh information concerning the a unique role played by The Times in influencing government policies

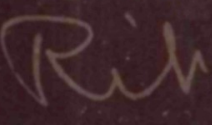




\section{THE TIMES AND APPEASEMENT}




\title{
THE TIMES AND APPEASEMENT
}

The Journals of A. L. Kennedy, I932-1939

\author{
edited by \\ GORDON MARTEL
}

CAMDEN FIFTH SERIES

VOLUME I6

\section{CAMBRIDGE \\ ( UNIVERSITY PRESS}

FOR THE ROYAL HISTORICAL SOCIETY

University College London, Gower Street, London WCIE 6BT

2000 
Published by the Press Syndicate of the University of Cambridge

The Edinburgh Building, Cambridge $\mathrm{CB} 2$ 2RU, United Kingdom 40 West 2oth Street, New York, NY IOII-42II, USA ro Stamford Road, Oakleigh, Melbourne 3I66, Australia

(C) Royal Historical Society 2000

First published 2000

A catalogue record for this book is available from the British Library

Library of Congress cataloguing-in-publication Data

Kennedy, A. L. (Aubrey Leo), b. 1885.

The Times and appeasement: the journals of A. L. Kennedy, 1932I939/edited by Gordon Martel.

p. $\mathrm{cm}$. (Camden fifth series; v. I6)

ISBN o-52I-79354-8

I. Great Britain-Politics and government-1936-1945--Sources. 2. Great

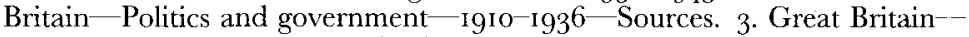
Foreign relations - $1910-1936$ - Sources. 4. Great Britain--Foreign relations-1936-1945-Sources. 5. Great Britain-Foreign relations-Germany-Sources. 6. Germany-Foreign relations-Great BritainSources. 7. Kennedy, A. L. (Aubrey Leo), b. I885--Diaries. 8. World War, I939-1945-Causes - Sources. 9. World politics I933-1945-Sources. Io. Times (London, England). I. Martel, Gordon. II. Title. III. Series.

$\mathrm{DA}_{20 . \mathrm{C}_{15}}$ v. 16

[DA578]

$94 \mathrm{I} .084-\mathrm{dc} 2 \mathrm{I}$

$0^{-} 05^{8} 533$

\section{ISBN o $5^{21} 79354^{8}$ hardback}

SUBSCRIPTIONS. The serial publications of the Royal Historical Society, Royal Historical Society Transactions (ISSN 0080-440I) and Camden Fifth Series (ISSN $0960^{-}-163$ ), volumes may be purchased together on annual subscription. The 2000 subscription price (which includes postage but not VAT is $f_{60}$ (US\$99 in the USA, Canada and Mexico) and includes Camden Fifth Series, volumes 15 and 16 (published in July and December) and Transactions Sixth Series, volume to (published in December). Japanese prices are available from Kinokuniya Company Ltd, P.O. Box 55, Chitose, Tokyo 156, Japan. EU subscribers (outside the UK) who are not registered for VAT should add VAT at their country's rate. VAT registered subscribers should provide their VAT registration number. Prices include delivery by air.

Subscription orders, which must be accompanied by payment, may be sent to a bookseller, subscription agent or direct to the publisher: Cambridge University Press, The Edinburgh Building, Shaftesbury Road, Cambridge CB2 2RU, UK; or in the USA, Canada and Mexico; Cambridge University Press, Journals Fulfillment Department, i o Midland Avenue, Port Chester, NY 105734930 , USA.

SINGLE VOLUMES AND BACK VOLUMES. A list of Royal Historical Society volumes available from Cambridge University Press may be obtained from the Humanities Marketing Department at the address above.

Printed and bound in the United Kingdom by Butler \& Tanner Ltd, Frome and London 
For

Elizabeth Le Mesurier [née Kennedy]

\&

Claire Heddy [née Kennedy] 


\section{GONTENTS}

Notes on the text

page

List of Abbreviations

$\mathrm{xi}$

Introduction

$\begin{array}{ll}1932 & 17\end{array}$

$1933+71$

$\begin{array}{ll}1934 & \text { I } 19\end{array}$

$\begin{array}{lr}1935 & \text { I57 }\end{array}$

$\begin{array}{lr}1936 & 189\end{array}$

$1937 \quad 245$

$\begin{array}{ll}193^{8} & 255\end{array}$

$\begin{array}{ll}1939 & 283\end{array}$

$\begin{array}{ll}\text { Appendix } & 295\end{array}$

$\begin{array}{ll}\text { Index } & 305\end{array}$ 